\title{
Juvenile morphology of the large Antarctic canopy-forming brown alga, Desmarestia menziesii J. Agardh
}

\author{
Frithjof C. Küpper ${ }^{1}\left[\begin{array}{l}(\text { C Charles D. Amsler } \\ 2\end{array}\right.$ \\ Lloyd S. Peck ${ }^{3}$ (i) $\cdot$ Akira F. Peters ${ }^{1,5}$
}

Received: 22 May 2019 / Revised: 31 August 2019 / Accepted: 4 September 2019 / Published online: 22 September 2019

(c) The Author(s) 2019

\begin{abstract}
For many types of seaweeds in Polar Regions, open questions remain about how their life cycle contributes to their overall adaptation to the extreme abiotic environment. This applies in particular to the major canopy-forming brown algae in much of the Antarctic Peninsula of the genus Desmarestia, which was investigated here. Diving surveys around Rothera Research Station (Adelaide Island, Antarctica) during December 2017-February 2018 revealed the widespread presence of a hithertounknown life form of Desmarestia sp. of a tender, feather-like morphology. Further studies explored whether this could be (1) a new, hitherto undescribed Desmarestia species (2) a new record for the region of a known Desmarestia species previously recorded elsewhere or (3) a so-far unknown life form of a species recorded for the region. Collections enabled the extraction of PCR-friendly DNA and sequencing of ITS1, which unambiguously showed that the samples belonged to Desmarestia menziesii, the only Desmarestia species presently recorded for the Adelaide Island/Marguerite Bay region. The presence of the juvenile morphology was subsequently confirmed throughout much of the natural range of D. menziesii during cruise-based diving surveys along the Western Antarctic Peninsula in 2019 and from collections at Anvers Island in 1989. Our collections thus constitute its juvenile morphology, which is not previously documented in the literature. The wider significance for the Polar seaweeds is discussed in the context of Taxonomy and Ecology.
\end{abstract}

Keywords Adelaide Island · Antarctic Peninsula $\cdot$ Desmarestia chordalis $\cdot$ Desmarestia menziesii $\cdot$ Desmarestia rossii . ITS · Southern Ocean

Electronic supplementary material The online version of this article (https://doi.org/10.1007/s00300-019-02584-3) contains supplementary material, which is available to authorized users.

Frithjof C. Küpper

fkuepper@abdn.ac.uk

1 School of Biological Sciences, University of Aberdeen, Cruickshank Building, St. Machar Drive, Aberdeen AB24 3UU, Scotland, UK

2 Department of Biology, University of Alabama at Birmingham, Birmingham, AL 35233-1405, USA

3 British Antarctic Survey, Natural Environment Research Council, High Cross, Madingley Road, Cambridge CB3 0ET, UK

4 Institut Systématique Evolution Biodiversité (ISYEB), Muséum national d'histoire naturelle, CNRS, Sorbonne Université, EPHE, UA, 57 rue Cuvier, CP 39, 75005 Paris, France

5 Bezhin Rosko, 40 rue des pêcheurs, 29250 Santec, Brittany, France

\section{Introduction}

The Antarctic has some of the most extreme environments on planet Earth. Its marine environment is characterized by low temperatures rarely exceeding the range of $-1.8-2{ }^{\circ} \mathrm{C}$ (Barnes et al. 2006). Compared to the sub-Antarctic region, the Antarctic is generally considered depauperate in terms of seaweed species diversity (Wiencke and Clayton 2002). Pioneering studies of Antarctic seaweed biodiversity, taxonomy and biogeography were conducted over a century ago by Skottsberg (Skottsberg 1907), with a recent synopsis provided by Wiencke and Clayton (2002). Adaptations of polar seaweeds enable them to survive at temperatures around freezing, and during months of darkness in winter (Wiencke et al. 2009). Contrasting with tropical and temperate bioregions, Polar Regions typically show an intertidal zone which is almost devoid of macroalgae. The reason for this are the extreme environmental conditions in the intertidal zone-where temperature extremes range from -50 
to $+5{ }^{\circ} \mathrm{C}$ (Peck et al. 2006; Waller et al. 2006), compounded by strong impacts of sea ice abrasion (Barnes and Souster 2011; Barnes et al. 2014), and the encasing of the intertidal by fast ice in the winter in all continental localities and year round in over $80 \%$ of the continent (Peck 2018). It is remarkable that the Antarctic phytobenthos has no representatives of the kelps (Laminariales), which occur in the Arctic and all cold-temperate bioregions worldwide. Their ecological niche and role, as providers of canopy, are mostly replaced by members of the Desmarestiales (Moe and Silva 1977), which were found to originate from cold waters of the southern hemisphere (Peters et al. 1997).

The northernmost parts of Antarctica-in particular, the South Shetland Islands, Anvers Island and the tip of the Antarctic Peninsula-are home to six Desmarestiales species, namely, D. anceps Montagne, D. antarctica R.L. Moe \& P.C. Silva, D. confervoides (Bory) M. Ramirez \& A.F. Peters and D. menziesii J. Agardh, as well as Himantothallus grandifolius (A. \& E. Gepp) Zinova and Phaeurus antarcticus Skottsberg. In contrast, the region of Adelaide Island and Marguerite Bay, about $500 \mathrm{~km}$ further south along the Antarctic Peninsula, is impoverished in many aspects of its marine flora. Poorly surveyed in this regard until recently, an inventory of its seaweed diversity was published only a few years ago (Mystikou et al. 2014). In this region, D. menziesii is the major canopy-forming species in the depth range of around 5-20 m, and the only Desmarestia species recorded.
The present study was triggered when a sample collected in late December 2017 appeared to be a hitherto-unrecorded Desmarestia species for this area, which had not been captured by the survey 7 years earlier (Mystikou et al. 2014). Given that it could not be identified morphologically with the existing literature for Antarctic seaweeds (Wiencke and Clayton 2002), the following hypotheses were tested within the framework of this study: (1) Is this a native, novel species, for some reason missed by the previous survey (Mystikou et al. 2014)? (2) Could it be a new arrival for the area, e.g. either due to climate change-linked poleward migration, or an alien species? and (3) Could it be another life form of a known species for the area?

\section{Materials and methods}

Algae were collected by SCUBA diving in the vicinity of Rothera Research Station, Adelaide Island, between Dec. 2017 and February 2018. Dive sites surveyed and details of the dives are displayed in Fig. 1a and listed in Supplementary Table 1, respectively.

Immediately following each day of diving, herbarium specimens were prepared by mounting seaweed thalli on Bristol paper. They were deposited in the herbarium of the British Museum - Natural History (BM), British Antarctic Survey (BAS, Cambridge, UK) and Muséum National

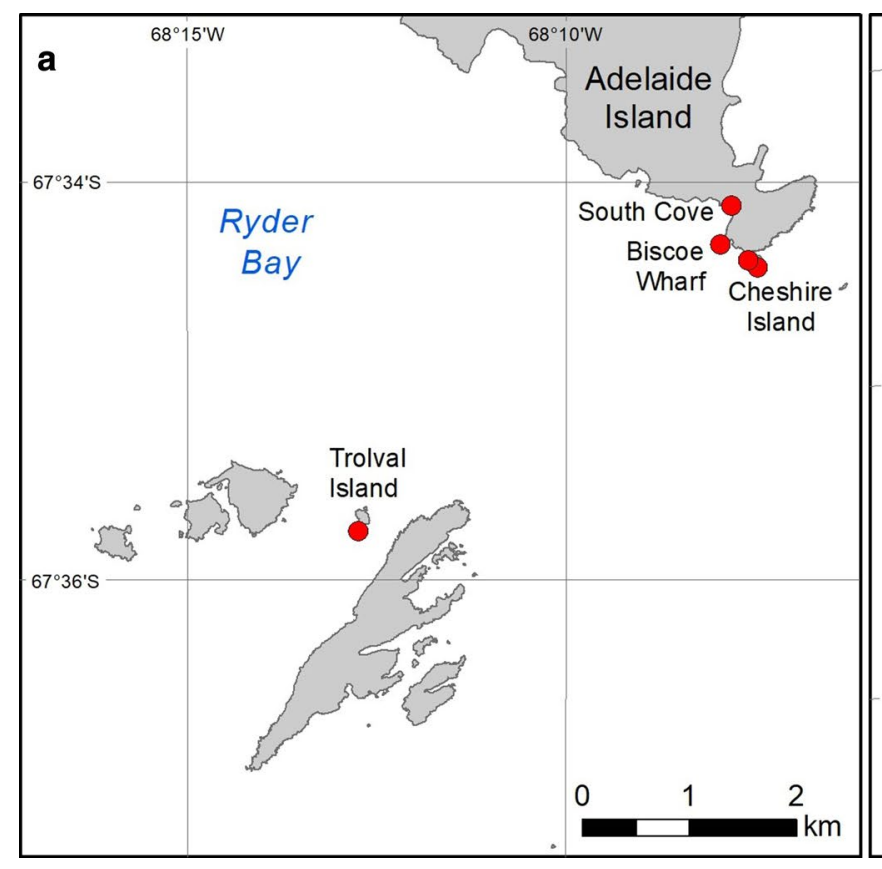

Fig. 1 Map of the study area with the dive sites. a The vicinity of Rothera Research Station surveyed in January 2018; b The sites along the Western Antarctic Peninsula surveyed in April 2019. The small square on Adelaide Island indicates the location of the map in Fig. 1a.

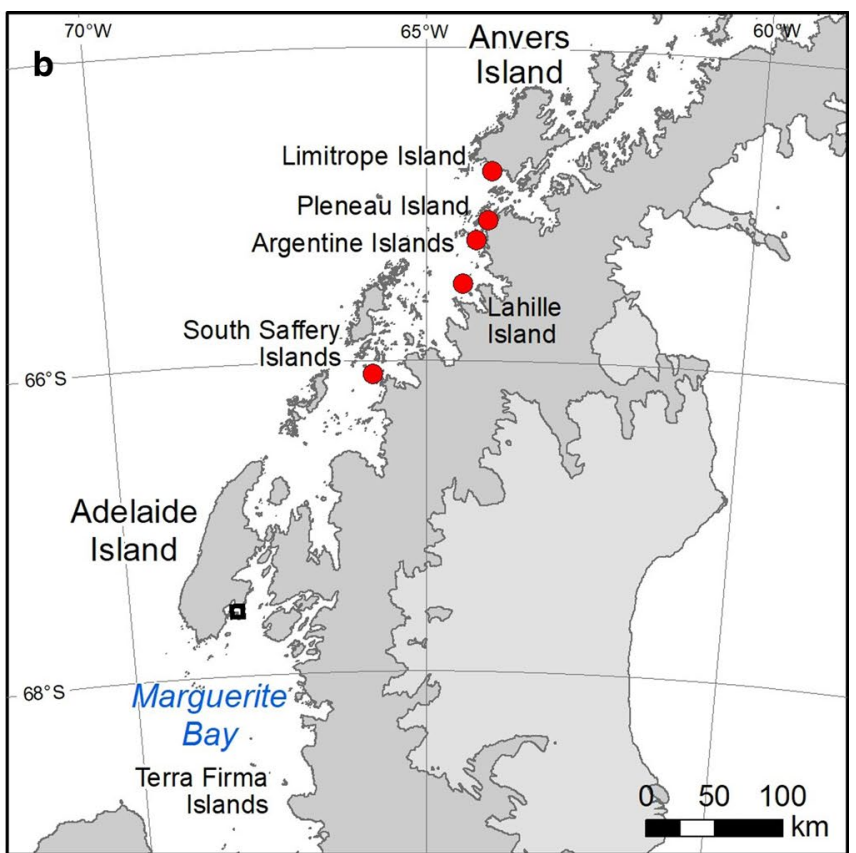

Red dots are dive sites and the open black square is Rothera Research Station. Source: Map produced by the British Antarctic Survey Mapping and Geographic Information Centre 
d'Histoire Naturelle - Cryptogamie (PC). Fragments of all specimens were kept in silica crystals or $96 \%$ ethanol, both of which conserve DNA for further molecular studies.

The diving work at Rothera was complemented by cruisebased diving surveys in April and May 2019 at 15 sites along the Western Antarctic Peninsula ranging from the Terra Firma Islands in Marguerite Bay (S 68 41.5', W $067^{\circ} 31.6^{\prime}$ ) to the Joubin Islands west of southern Anvers Island (S $64^{\circ}$ $46.4^{\prime}$, W $064^{\circ} 22.2^{\prime}$ ). Subsequently, we examined voucher material collected from several other small islands off southern Anvers Island in 1989 (Amsler et al. 1995). Dive sites surveyed and details of the dives are displayed in Fig. $1 \mathrm{~b}$ and listed in Supplementary Table 1, respectively.

DNA was extracted on samples \# 180118-1.1 and \# 180118-1.2 using CTAB buffer as described previously (Gachon et al. 2009). Polymerase chain reactions (PCR) were employed to amplify a fragment of the nuclear ribosomal DNA containing 3'-SSU, ITS1, and partial 5.8S, using the primer pair ITS1/KIR1, ITS1 (5' TCCGTAGGTGAA CCTGCGG 3'; White et al. 1990)) and K1R1 (5' TTCAAA GTTTTGATGATT 3'; Lane et al. 2006). PCR was carried out with an initial denaturation at $94{ }^{\circ} \mathrm{C}$ for $3 \mathrm{~min}$, followed by 35 cycles of amplification consisting of denaturation at $94{ }^{\circ} \mathrm{C}$ for $30 \mathrm{~s}$, annealing at $50{ }^{\circ} \mathrm{C}$ for $30 \mathrm{~s}$, and then elongation at $72{ }^{\circ} \mathrm{C}$ for $1 \mathrm{~min}$. The 35 cycles were followed by a final extension at $72{ }^{\circ} \mathrm{C}$ for $5 \mathrm{~min}$. PCR amplification was performed in a total volume of $25 \mu \mathrm{L}$, containing 0.25 units $\mu \mathrm{L}^{-1}$ of $T a q$ DNA Polymerase (Promega), $1 \times$ GoTaq Buffer, $5 \mathrm{mM} \mathrm{MgCl}{ }_{2}, 0.5 \mathrm{mM}$ dNTPs, $0.3 \mathrm{mM}$ of each primer and $1.7 \mu \mathrm{L}$ of template DNA. The DNA sequence obtained was aligned manually with $\mathrm{Se}-\mathrm{Al}^{\mathrm{TM}}$ v2.0a11 (Sequencing Alignment Editor Version 2.0 alpha 11; https ://tree.bio.ed.ac.uk/software/seal/) and meticulously checked for correctness by inspecting the chromatograms.

Identification of herbarium specimens, and live field material was attempted using available keys, in particular that of Wiencke and Clayton (2002). For present-day taxonomic and nomenclatural aspects, AlgaeBase (Guiry and Guiry 2018) was consulted.

Furthermore, the collections of the British MuseumNatural History (BM), of the Muséum National d'Histoire Naturelle - Cryptogamie (PC), and of the University of California, Berkeley (UC) were searched for any specimens from the Antarctic labelled as Desmarestia menziesii, or corresponding to the morphology (but possibly labelled under different taxonomic names) described here.

\section{Results}

An unknown Desmarestia sp., initially found during a dive at the Biscoe Wharf, was subsequently observed at most sites surveyed (Table S1; Figs. 2 and 3). It intrigued the

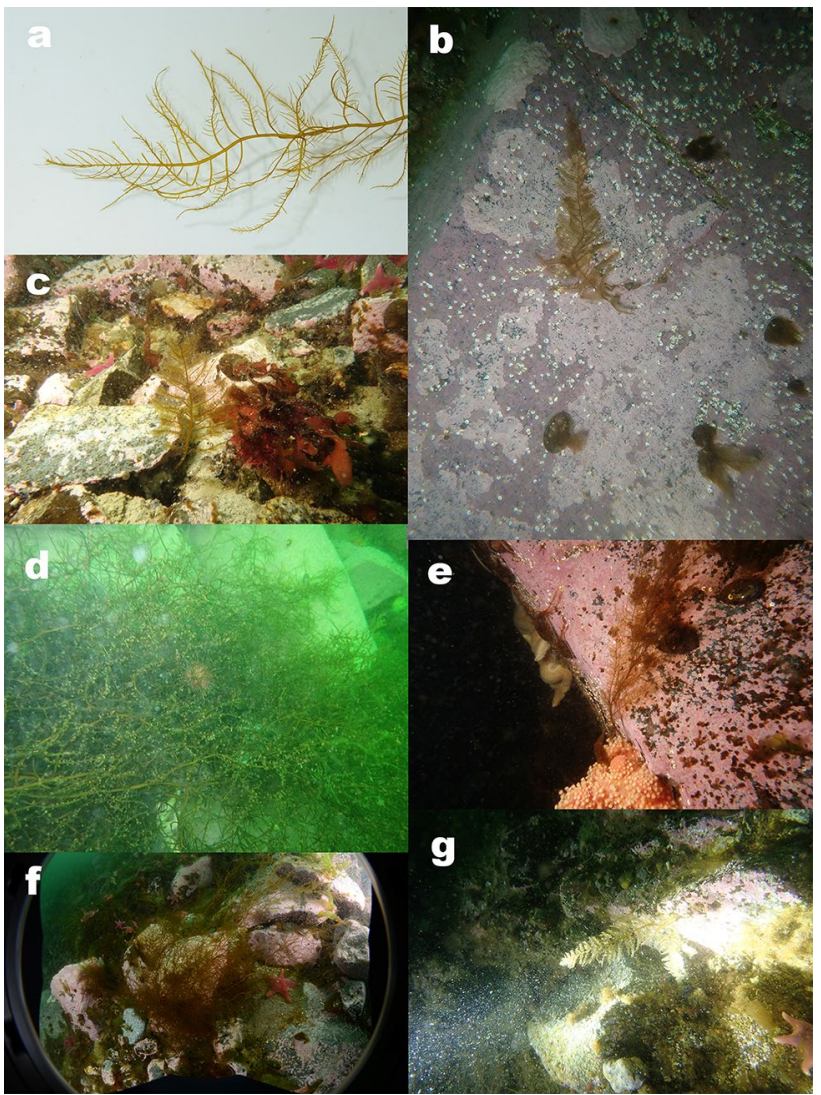

Fig. 2 Desmarestia menziesii from the sublittoral in the vicinity of Rothera Point, Adelaide Island. The juvenile form described here a Macrophotograph in the laboratory; $\mathbf{b}, \mathbf{c}, \mathbf{e}$, and $\mathbf{g}$ in situ in the sublittoral. For comparison, $\mathbf{d}, \mathbf{f}$ the perennial form in situ with the morphology so far described in the literature

investigators by its regular pinnate (feathery) appearance with opposite laterals, which did not appear in accordance with the more irregular branching in adult $D$. menziesii. The morphology rather resembled juvenile $D$. anceps Montagne (Wiencke et al. 1996), which had not been reported from the Adelaide Island area.

Since it was impossible to identify it using keys based on morphology-based criteria (in particular, Wiencke and Clayton 2002), a molecular approach, relying on sequencing ITS1 (Internal Transcribed Spacer 1) was chosen. A partial sequence was obtained (MK506123) and aligned with ITS1 sequences of other Desmarestia species (Genbank accession number MK506123; Suppl. Fig. S1). It showed $100 \%$ identity with D. menziesii from King George Island, obtained from a male gametophyte isolated in 1986 (accessions Z84448 and HE866886) and a public sequence identified only to genus (accession MF419243), also from King George Island, and high similarity with adult D. menziesii collected at Candlemas Island in 1998 (AJ243781; two indels which could have been misreadings in manually sequenced AJ243781). Other Desmarestia species were 
Fig. 3 Herbarium specimens of Desmarestia menziesii originating from this study deposited at PC. a Juvenile and $\mathbf{b}$ adult morphology

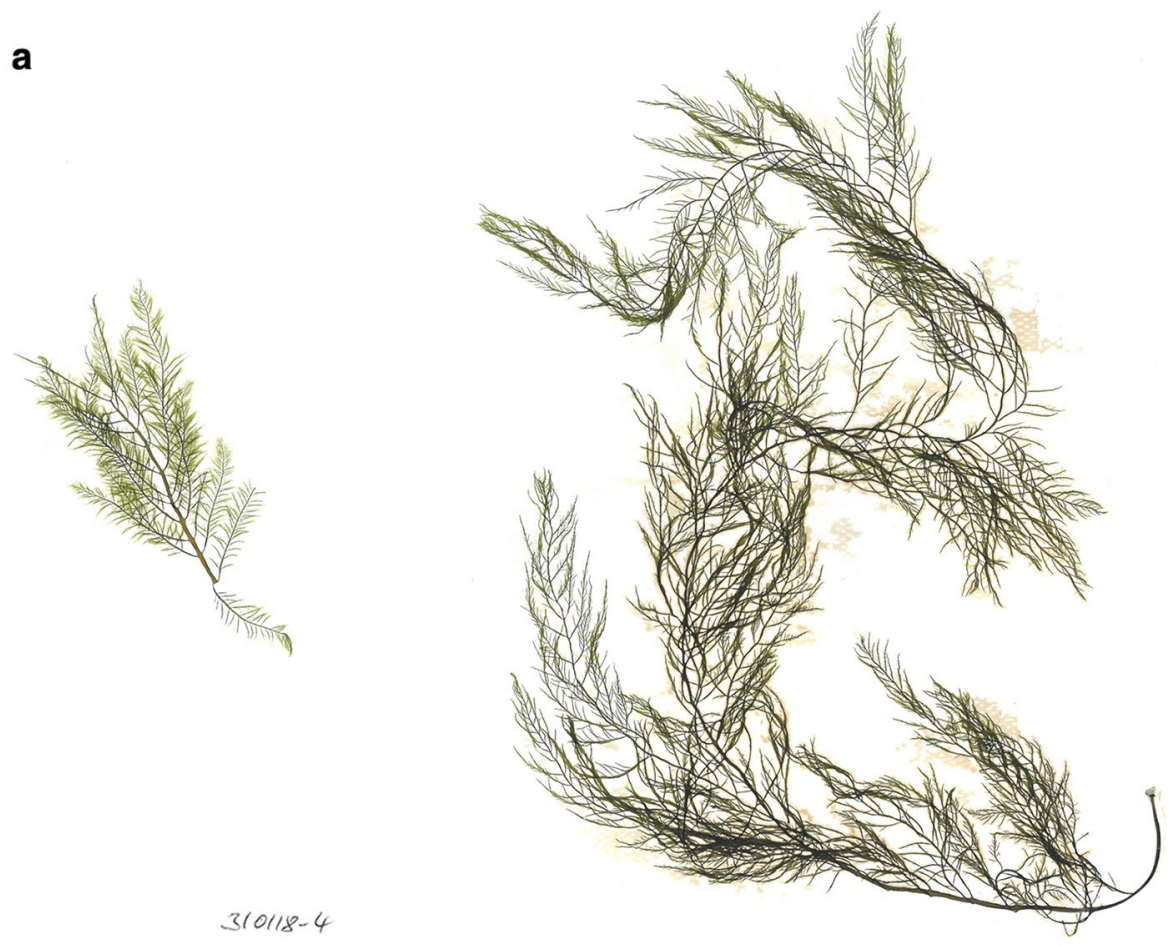

$310118-7.5$

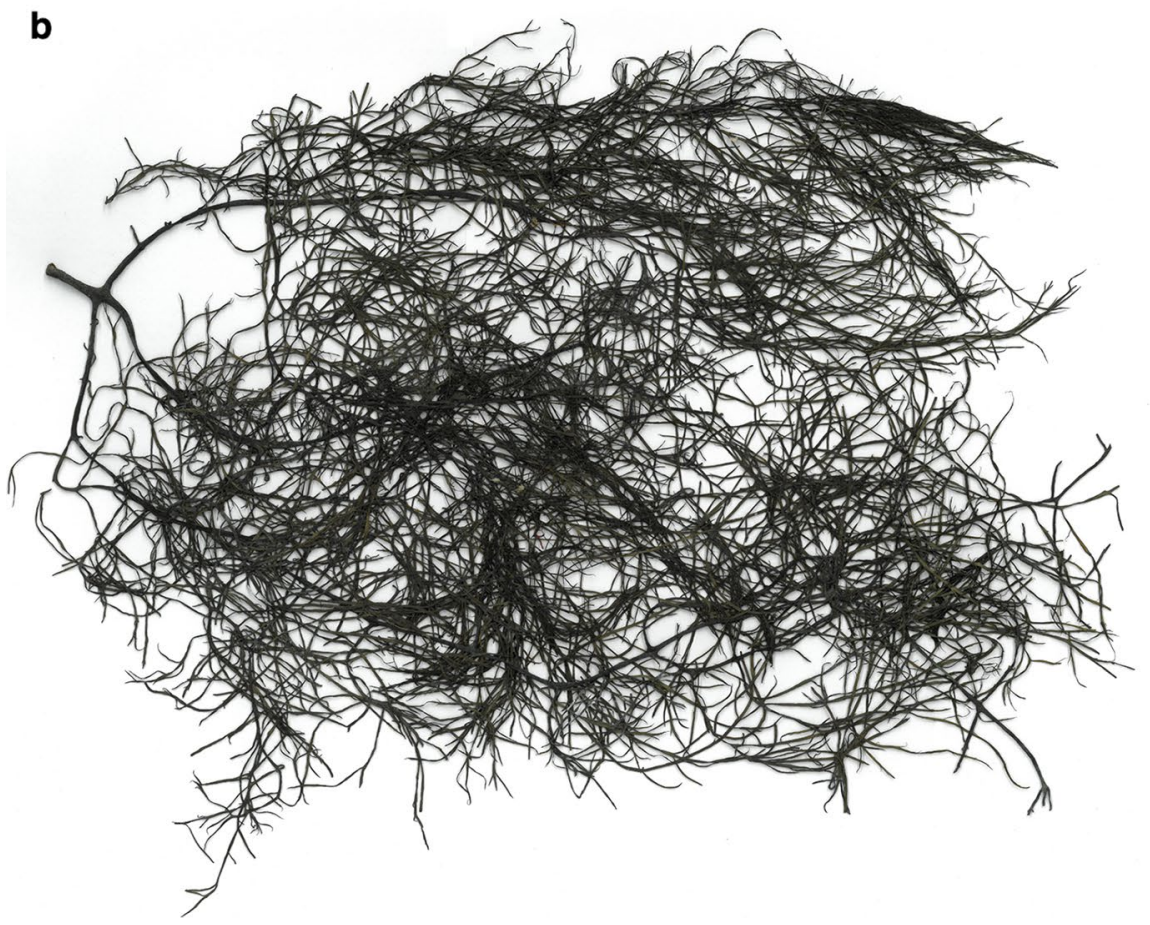

more different. The sequence of sub-Antarctic D. chordalis (HE866859) differed by two C-T substitutions, and the sequences of Antarctic D. anceps and D. antarctica were evidently more different (Supplementary Fig. S1).
Subsequently, a survey of 15 sites between Marguerite Bay and southern Anvers Island recorded the typical morphology of D. menziesii from the southernmost end of the survey (Terra Firma Islands) and two other sites in Marguerite Bay but did not observe the feathery form there. The 
feathery form was observed at the South Saffery Islands (S $66^{\circ} 05.4^{\prime}$ ) and four other sites between there and southern Anvers Island (Fig. 1b; Table S1). At the South Saffery Is. site, the typical $D$. menziesii was observed at a depth ranging from 5 to $12 \mathrm{~m}$ depth range with the smaller feathery form seen only at a depth range from 15 to $30 \mathrm{~m}$. However, at other sites, the feathery form and normal forms of D. menziesii and/or D. anceps were found throughout the 5-35-m depth range surveyed.

A search of BM and PC did not uncover any specimens corresponding to the morphology of the Desmarestia found at Rothera. However, a search of the UC Herbarium revealed five specimens that correspond to the juvenile morphology (UC 1,571,530, 1,571,531, 1,571,533 and 1,571,534 from Arthur Harbor, Anvers Island; 1,571,532 from Lavebrua Island, Deception Island). Interestingly, they are labelled "D. menziesii", but this morphology has not been described anywhere (R.L. Moe, personal communication). A subsequent search of voucher material in the personal herbarium of C.D. Amsler from a March-April 1989 survey at several sites off Anvers Island (Amsler et al. 1995) revealed multiple individuals with the juvenile morphology. These were collected throughout the 2-20-m depth range surveyed in the study along with the typical morphological forms of both $D$. menziesii and $D$. anceps.

\section{Discussion}

The juvenile form of $D$. menziesii described in this paper was identified using a partial ITS1 sequence (MK506123) aligned with published sequences. For this marker, numerous sequences from other Desmarestiales, including all other Desmarestia species known from Antarctica, had previously been obtained (van Oppen et al. 1993; Peters et al. 1997; Yang et al. 2014). The sequence of a highly variable part of the barcode marker ITS1 obtained from the unknown entity collected during the diving surveys around Rothera corresponds unambiguously to that of D. menziesii from King George Island. Beyond any doubt, this supports the conclusion that the previously unknown entity described here, which we collected at Rothera, is not a new species or a new record of another known Desmarestia species occurring elsewhere in the Antarctic, but a hitherto-unknown life form of a very common Southern Ocean seaweed. Indeed D. menziesii is of one of the major canopy-forming seaweeds in Antarctic waters. The small size of our specimens and clear early-stage colonization in the majority of cases makes it reasonable to conclude that the morphology of this entity is a juvenile form of D. menziesii (Fig. 3a for herbarium specimens), and that the established wiry morphology of $D$. menziesii as it is described in the literature corresponds to the adult/perennial form. This latter adult wiry morphology occurs widely in the $D$. menziesii canopy around Rothera (Fig. 2 in situ; Fig. $3 \mathrm{~b}$ for a herbarium specimen).

In culture, juvenile $D$. menziesii sporophytes with opposite and alternate laterals have been observed (Wiencke et al. 1995). However, one-level intercalary meristems have never been seen in both opposite laterals (Wiencke, personal communication). An intercalary meristem developed in one of the opposite laterals only, not in both. The other opposite lateral degenerated and later vanished (Wiencke, personal communication).

A search of BM and PC did not uncover any specimens corresponding to the morphology described here for our field samples, yet a search in UC uncovered five specimens of this morphology. All specimens held in BM and PC and labelled " $D$. menziesii" have the known, wiry morphology, likely belonging to the perennial adult form (Fig. 3b), suggesting that previous investigations have missed the juvenile form, and live cultures do not seem to have been raised to this size yet.

In this context, it has to be mentioned that there seems to be some uncertainty attached to the application of the name $D$. menziesii. When providing the initial description, J. Agardh (Agardh 1848) stated that it was based on specimens collected by Menzies in the South Shetland Islands and by Bory in Concepción, Chile. But Menzies had retired from the Navy long before the South Shetland Islands were discovered, and it is unlikely that the same species of Desmarestia occurs in temperate Chile and the high Antarctic (R. L. Moe, pers. comm.). The species collected by Bory at Concepción is $D$. confervoides.

The reasons for the strong dimorphism within D. menziesii and other Antarctic Desmarestia species remain unknown at present, but a plausible hypothesis is that the samples with a seemingly novel morphology is the juvenile form, appearing briefly before spending winter under sea ice, while the entity with the well-documented morphology in the literature (Wiencke and Clayton 2002) is the longlived, perennial form. This is consistent with the specimens collected in 1989 and 2019, all of which were from late in the growing season (March to May) when young plants might be expected to become apparent. This is also a time when relatively few scientists make diving collections along the WAP, which may explain why the morphology has been rarely seen and never before documented in the literature. Indeed, survival during prolonged periods under sea ice, possibly in combination with ice abrasion and at least potential intense herbivory, may be a strong factor resulting in a more sturdy morphology in certain polar seaweeds. A few analogous cases are known. The first is that of Desmarestia chordalis J.D.Hooker \& Harvey, where juvenile individuals were described under the name $D$. rossii J.D.Hooker \& Harvey (Reviers unpublished observations in Kerguelen Islands, 1977; Fischer et al. 1987; Ricker 1987). 
The juvenile sporophytes of $D$. menziesii resemble juvenile sporophytes of $D$. anceps, which may be a typical feature of field material (Wiencke et al. 1996). Another one is that of the Arctic Platysiphon glacialis (Kawai et al. 2015), replacing two previously separately described entities: Platysiphon verticillatus R.T. Wilce and Platyarcticus glacialis (Rosenvinge) R.T.Wilce \& P.M.Pedersen.

The description here of a newly reported juvenile morphology of D. menziesii has wider implications for understanding the recruitment of canopy-forming seaweed communities in Antarctica, and we can only conjecture as to how many more examples there may be of undescribed juvenile forms of Antarctic macroalgae. Given the extreme variations in open water and ice scour from year to year and from place to place and given the difficulty of longitudinal observation in the Antarctic, environmental sequencing might reveal cryptic diversity in the form of endophytic or endozooic stages. Further, significant questions in this context are whether the gametophytes have special requirements, and whether they are long lived and were present even where no sporophytes are found.

Acknowledgements We are grateful to the UK Natural Environment Research Council for funding to FCK (grants NE/D521522/1 and NE/ J023094/1), in particular through the Collaborative Antarctic Science Scheme (Grant CASS-134, 2017) to FCK and LSP. Funding for cruisebased observations in 2019 was from US National Science Foundation award OPP-1744550 to CDA. We thank Kate Stanton, Teresa Murphy and Ben Robinson (British Antarctic Survey) for support with diving operations around Rothera in January-February 2018, and also Richard L. Moe (UC Berkeley) for locating specimens corresponding to the morphology described here in the UC collection. Special thanks are due to Charlie Bibby (Financial Times) for taking professional photographs of the unknown Desmarestia sp. in the aquarium of the Bonner Lab at Rothera (Fig. 2a). We would also like to thank Richard L. Moe (UC Berkeley) and Christian Wiencke (AWI Bremerhaven) for their very helpful reviews of this paper. Also, the MASTS pooling initiative (Marine Alliance for Science and Technology for Scotland, funded by the Scottish Funding Council and contributing institutions; grant reference HR09011) is gratefully acknowledged for supporting FCK. This research contributes to the SCAR Ant-ERA research programme.

\section{Compliance with ethical standards}

Conflict of interest There are no conflicts of interest to disclose.

Open Access This article is distributed under the terms of the Creative Commons Attribution 4.0 International License (http://creativeco mmons.org/licenses/by/4.0/), which permits unrestricted use, distribution, and reproduction in any medium, provided you give appropriate credit to the original author(s) and the source, provide a link to the Creative Commons license, and indicate if changes were made.

\section{References}

Agardh J (1848) Species genera et ordines algarum, seu descriptiones succinctae specierum, generum et ordinum, quibus algarum regnum constituitur. Volumen Primum. Algas fucoideas complectens. C.W.K, Gleerup, Lundae

AlgaeBase. World-wide electronic publication. https://www.algaebase. org (2018) National University of Ireland, Galway. https://www. algaebase.org. Accessed 11/08/2018

Amsler CD, Rowley RJ, Laur DR, Quetin LB, Ross RM (1995) Vertical distribution of Antarctic Peninsular macroalgae-cover, biomass and species composition. Phycologia 34:424-430. https://doi. org/10.2216/i0031-8884-34-5-424.1

Barnes DKA, Souster T (2011) Reduced survival of Antarctic benthos linked to climate-induced iceberg scouring. Nat Clim Chang 1:365-368. https://doi.org/10.1038/nclimate1232

Barnes DKA, Fenton M, Cordingley A (2014) Climate-linked iceberg activity massively reduces spatial competition in Antarctic shallow waters. Curr Biol 24:R553-R554. https://doi.org/10.1016/j. cub.2014.04.040

Barnes DKA, Fuentes V, Clarke A, Schloss IR, Wallace MI (2006) Spatial and temporal variation in shallow seawater temperatures around Antarctica Deep-Sea Research Part II. Top Stud Oceanogr 53:853-865. https://doi.org/10.1016/j.dsr2.2006.03.008

Fischer W, Hureau J-C, eds (1987) Fiches FAO d'identification des espèces pour les besoins de la pêche. Océan Austral (Zones de pêche 48, 58 et 88) (Zone de la Convention CCAMLR). Publication préparée et publiée avec l'aide de la Commission pour la conservation de la faune et de la flore marines de l'Antarctique. vol 1. FAO, Rome

Gachon CMM, Strittmatter M, Müller DG, Kleinteich J, Küpper FC (2009) Differential host susceptibility to the marine oomycete pathogen Eurychasma dicksonii detected by real time PCR: not all algae are equal. Appl Environ Microbiol 75:322-328

Kawai H et al (2015) Reproductive morphology and DNA sequences of the brown alga Platysiphon verticillatus support the new combination P. glacialis. J Phycol 51:910-917. https://doi.org/10.1111/ jpy. 12331

Lane CE, Mayes C, Druehl LD, Saunders GW (2006) A multi-gene molecular investigation of the kelp (Laminariales, Phaeophyceae) supports substantial taxonomic re-organization (Vol 42, pg 493). J Phycol 42:962-962. https://doi.org/10.111 1/j.1529-8817.2006.00253.x

Moe RL, Silva PC (1977) Antarctic marine flora: uniquely devoid of kelp. Science 196:1206-1208. https://doi.org/10.1126/scien ce.196.4295.1206

Mystikou A et al (2014) Seaweed biodiversity in the south-western Antarctic Peninsula: surveying macroalgal community composition in the Adelaide Island/Marguerite Bay region over a 35-year time span. Polar Biol 37:1607-1619. https://doi.org/10.1007/ s00300-014-1547-1

Peck LS (2018) Antarctic marine biodiversity: adaptations, environments and responses to change. Oceanogr Mar Biol Annu Rev 56:105-236

Peck LS, Convey P, Barnes DKA (2006) Environmental constraints on life histories in Antarctic ecosystems: tempos, timings and predictability. Biol Rev 81:75-109. https://doi.org/10.1017/s1464 793105006871

Peters AF, van Oppen MJH, Wiencke C, Stam WT, Olsen JL (1997) Phylogeny and historical ecology of the Desmarestiaceae (Phaeophyceae) support a southern hemisphere origin. J Phycol 33:294-309

Ricker RW (1987) Taxonomy and biogeography of Macquarie Island seaweeds. British Museum Natural History, London 
Skottsberg C (1907) Zur. Kenntnis der subantarktischen und antarktischen Meeresalgen. I. Phaeophyceen. Kungl. Boktryckeriet. P.A. Norstedt \& Söner, Stockholm

van Oppen MJH, Olsen JL, Stam WT, Wiencke C (1993) Arctic-Antarctic disjunctions in the benthic seaweeds Acrosiphonia arcta (Chlorophyta) and Desmarestia viridis/willii (Phaeophyta) are of recent origin. Mar Biol 115:381-386

Waller CL, Barnes DKA, Convey P (2006) Ecological contrasts across an Antarctic land-sea interface. Austral Ecol 31:656-666. https:// doi.org/10.1111/j.1442-9993.2006.01618.x

White TJ, Bruns T, Lee S, Taylor JW (1990) Amplification and direct sequencing of fungal ribosomal RNA genes for phylogenetics. In: Innis MA, Gelfand DH, Sninsky JJ, White TJ (eds) PCR protocols: a guide to methods and applications. Academic Press Inc., New York, pp 315-322

Wiencke C, Clayton MN (2002) Antarctic seaweeds. A.R.G Gantner, Liechtenstein

Wiencke C, Clayton MN, Langreder C (1996) Life history and seasonal morphogenesis of the endemic Antarctic brown alga Desmarestia anceps Montagne. Bot Mar 39:435-444. https://doi.org/10.1515/ botm.1996.39.1-6.435

Wiencke C, Clayton MN, Schulz D (1995) Life history, reproductive morphology and development of the Antarctic brown alga Desmarestia menziesii. J Agardh Bot Acta 108:201-208

Wiencke C, Gomez I, Dunton K (2009) Phenology and seasonal physiological performance of polar seaweeds. Bot Mar 52:585-592

Yang EC et al (2014) Ligulate Desmarestia (Desmarestiales, Phaeophyceae) revisited: $D$. japonica sp. nov. and $D$. dudresnayi differ from D. ligulata. J Phycol 50:149-166. https://doi.org/10.1111/ jpy. 12148

Publisher's Note Springer Nature remains neutral with regard to jurisdictional claims in published maps and institutional affiliations. 